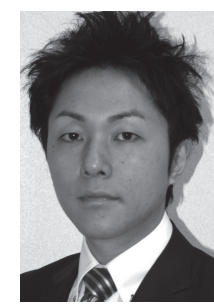

$$
\text { マルチスケールメカニクス }{ }^{\dagger}
$$

青 柳 吉 輝*

\title{
Multiscale Mechanics
}

by

Yoshiteru AOYAGI*

異なるスケールの情報を同時に考える「マルチスケー ル」という概念は材料分野のみならず理工学分野におけ る様々な難題の突破口として活用されています。

近年, 構造材料の大部分に炭素瀻維強化プラスチック を用いたボーイング787が就航するなど, 従来の性能を 凌駕する新材料の開発によって, あらゆる構造物の設計 の可能性が広がってきています, また, 我々の日常生活 に必要不可欠な鉄, 鋼, アルミニウムといった金属材料 および樹脂，繊維，ゴムといった高分子材料は，過酷な 状況下での使用や構造物の軽量化を目的として日々進化 を続けています．構造材料としてのみならず，汎用性の 高い最先端材料の成型性や信頼性を高めるために，その 力学特性を材料の微視的挙動から理解し, 変形挙動をよ り的確に表現可能な数理モデルの構築に期待が寄せられ ています。一方で, 航空機や自動車などの設計に使用さ れる $\mathrm{CAE}$ 技術はここ 10 年で驚くべき進歩を遂げ, CAE技 術なしには航空機や自動車を開発することができないと いっても過言ではありません. しかしながら, 近年開発 された最先端材料は複雑から異方的な組織を有している ことがあり, 既存の材料には見られない特異な力学特性 を示すことがあります. 構造用材料の変形挙動は経験的 現象論に基づく連続体塑性論などを用いて解析されるこ とが多いですが, 特異な力学特性を有する最先端材料に 従来の連続体理論をそのまま適用することはできません。 沉用性の高い最先端材料としての成形性や信頼性を高め るためには, その力学特性を材料の微視的観点から理解 するマルチスケールメカニクスという概念が必要不可欠 であると著者は考えております。著者はこれまでに, 結 晶構造に関する原子スケールと, 中間的な集合的結晶又 ケール, 構造体を巨視的に捉える連続体スケールといっ た異なるスケールの現象を同時に表現するモデル，すな わちマルチスケールモデルを構築し, 材料の複雑な振る 舞いを計算シミュレーションによって解析してきました. さらに, 実験によって得られたデー夕と計算的研究とを 融合させることによって, 新しい知見を生み出すことを 目的に次のような研究を行っています。

粒界・粒内転位源に基づくUFGメタルの力学特性予 測シミュレーション

金属材料の結晶粒径を小さくしていくと機械的力学特
性が向上することが経験的に知られています。しかしな がら,結晶粒径が 1 um以下という「UFG(Ultrafine-grained) メタル」の場合, これまでの常識が通用しないような力 学特性を示しますが, その微視的メカニズムについては 十分に解明されていないのが現状です。当研究室では, 転位源としての粒界の役割を考慮したマルチスケール結 晶塑性モデルを構築しました. 本モデルを用いたFEM解 析によってUFGMの特異な力学特性（FCC 金属の降伏点 降下現象，焼鈍硬化，加工軟化）を表現することができ ます. また, 実験で測定した金属微細組織の情報に基づき, 巨視的な降伏関数の予測にも成功しています.

\section{結晶性・非晶性ポリマの微視的変形機構に基づく高分 子塑性論の構築}

結晶性高分子材料は, 分子鎖が規則正しく配列されてい る結晶質掞よびランダムコイル構造を有する非晶質部分を 有します. 特に, 結晶質部分は結晶相と非晶相のラメラ構 造が織りなす球晶構造という複雑な組織を有します。この ような材料に関する研究に対して工業的な要請は強いもの の, 各相の特性について全く未知な部分が多いのが現状で す. 当研究室では, 球晶の変形挙動に関する実験観察に基 づき, 結晶質部分と非晶質部分の混在する結晶性高分子塑 性モデルを構築しています. 成型条件の違いによる結晶化 度の変化を実験的に確認し, 結晶化度に依存した弾性率 降伏応力の変化など, 高分子の微細組織の情報に基づいた 力学特性予測を行っています (図1).

現在著者が所属している東北大学大学院工学研究科ナ ノメカニクス専攻は2016年4月にファインメカニクス専 攻へと名称を変更します. 新たな研究・学術分野の創成 を目指すべく, 著者もマルチラテラルに日々精進し成長 していきたいと思います。

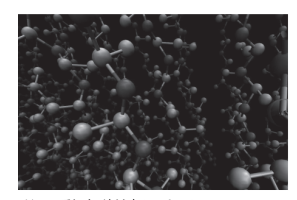

分子動力学法による 結晶質部分のシミュレーション

図 1

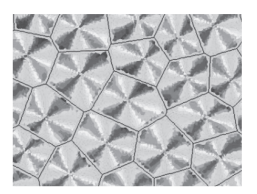

高分子塑性論による

球晶シミュレーション

高分子材料の階層構造

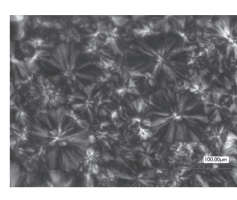

偏光顕微鏡による 球晶観察

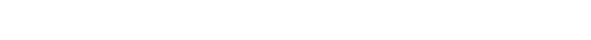

$\dagger$ 原稿受理 平成 28 年 1 月 12 日 Received Jan. 12, 2016 C2016 The Society of Materials Science, Japan

* 正会員 東北大学大学院工学研究科ナノメカニクス専攻 † 980-8579 仙台市青葉区荒卷字青葉, Dept. of Nanomech., Tohoku Univ., Aoba-ku, Sendai, 980-8579 